\title{
Exkluze v liberálním státě: Prípad politiky imigrace a občanství
}

\author{
Exclusion in the Liberal State. The Case of Immigration and \\ Citizenship Policy
}

\section{Christian Joppke}

ABSTRACT Recent literature on the "exclusions" of the modern nation-state has missed a major transformation in the legitimate mode of excluding, from group- to individual-based. This transformation is explored in a discussion of universalistic trends in contemporary Western states' immigration and citizenship policies. Conflicting with the notion of a "nation-state" owned by a particular ethnic group or nation, these trends are better captured in terms of a "liberal state" that has self-limited its sovereign prerogatives by constitutional principles of equality and individual rights. Key words: citizenship, discrimination, immigration, liberalism, nations and nationalism.

KEY WORDS Citizenship, discrimination, imigration, liberalism, nations and nationalism

Převládající model organizování národního státu v moderní době - západní národní stát - je poznamenán napětím mezi univerzalistickým liberalismem a partikulárním nacionalismem. Univerzalistický liberalismus usiluje o rovná práva a svobody pro všechny své členy, partikulární nacionalismus se snaží zabránit přístupu k výsadám všem, kdo nejsou členy. Již od slavného postřehu Johna Stuarta Milla (1991: 310), že ,existence svobodných institucí je v zemi tvořené různými národnostmi téměř nemožná“", se často zdůrazňuje, že se nejedná pouze o volnou soutěž protikladných a neslučitelných sil: vznešená fasáda rovnosti a svobody údajně spočívá na nečestných základech nacionalismu, který poskytuje stejnorodost a prostorovou ohraničenost, bez níž by liberalismus nemohl vzkvétat. Někteří se pokusili o nemožné skrze „liberální nacionalismus“ (Tamir, 1993; Miller, 1995), zatímco další ponechali tento rozpor rozporem a namísto toho odhalili liberalismus liberálů jako příklad zlého úmyslu (nejnověji Wimmer, 2002 a Marx 2003 a níže).

Pozoruhodným faktem zůstává, že rozhodnutí určující příslušenství $\mathrm{k}$ danému státu předchází, a je tedy imunní vůči silám liberalismu a má tendenci být sdíleno napříč politicko-filosofickými pozicemi. Joseph Carens (1987: 252) pranýřoval z kosmopolitní perspektivy občanství v západních liberálních demokraciích jako „moderní obdobu feudálních výsad“, protože je zpravidla přiděleno při narození, spíše než aby bylo svobodně zvolenou charakteristikou; Michael Walzer (1983: 61 a dále) obhajoval z komunitaristické perspektivy ,při-

Sociální studia. Fakulta sociálních studií Masarykovy univerzity , 1/2006. S. 55-72. ISSN 1212-813X.

Překlad převzat z: Joppke, Ch. 2005. „Exclusion in the Liberal State: The Case of Immigration and Citizenship Policy“. European Journal of Social Theory, 8 (1): 43-61.

(C) SAGE Publications, 2005. Publikováno se svolením Sage Publications Ltd., www.sagepublications.com 
dělování členstvi““ jako akt „nepodléhající vše-prostupujícímu nátlaku spravedlnosti“, protože jinak by nemohla existovat morálně vyspělá společenství (communities of character); Claus Offe (1998: 117) ze sociálně-demokratické perspektivy shledává, že „demokratická teorie nebo ústavní doktrína neposkytují dostatečné důvody $\mathrm{k}$ tomu, proč by sociální dimenze měla být tím, čím ve skutečnosti je“, a domnívá se, že je to tak v pořádku, protože pouze danost „území“ nebo „národa“ může poskytnout záruku „,stejnorodosti“, která je nezbytným předpokladem liberální demokracie; a Will Kymlicka (1995:124) z liberálně nacionalistické perspektivy odvozuje legitimitu práv menšin od předpokládaného neomezeného „,práva států rozhodovat o tom, kdo má občanství", čímž považuje práva menšin za jistou kompenzaci axiomaticky přepokládaného partikularistického budování národa v moderních státech. ${ }^{1}$

Inherentní partikulárnost národního státu je často shrnována v pojetí „vlastnictvi““ státu jistou národní nebo etnickou skupinou za cenu „exkluze“ všech skupin, které nejsou národní či etnické (nejradikálněji Wimmer 2002; historicky a geograficky citlivěji odstíněno v Marx 2002, 2003). V tomto článku zastávám názor, že všeobecně dostupná literatura o národech a nacionalismu neodpovídá politické a právní skutečnosti. ${ }^{2}$ Přinejmenším pro současný západní stát v „severoatlantické bezpečností zóně“ (Deutsch 1957) navrhuji místo toho více odpovídající obraz státu jakožto „liberálního státu“, který omezil své nároky na suverenitu ústavním zavázáním se $\mathrm{k}$ principům rovnosti a práv jednotlivce. Podporuji tento názor empirickým označením domovské půdy pojmu výhradní „vlastnictvi““: oblasti imigrační politiky a politiky občanství, skrze které je stanoveno členství ve státě. Měli bychom tento konstrukt zavrhnout, pokud jej nemůžeme nalézt ve zde uvedeném nejpravděpodobnějším př́ípadě platnosti tohoto konstruktu „vlastnictvi““ (King a spol. 1994: 209).

Avšak zdá se, že alternativní obraz liberálního státu omezeného ústavou vytváří paradox: jak mohou politiky, které upravují provždy partikulární hranice určité společnosti, být nositeli anonymních znaků univerzalismu a nediskriminace; nejsou partikularismus a diskriminace vepsány do samotných teorií těchto politik, jak je to uznáno v konstruktu mezinárodního práva $\mathrm{v}$ (téměř $)^{3}$ neomezené státní suverenitě $\mathrm{v}$ záležitostech imigrační politiky a národnostního zákona? V první části přistupuji k těmto námitkám záporně, přičemž poukazuji na některé

1 V pozdější stati (2002) Kymlicka rozpracoval názor více zohledňující jemné odlišnosti vztahující se k ,sebe-limitujícímu“ budování národa v současných liberálních státech, uhýbá však před nepř́íjemnými implikacemi vztahujícími se na jeho ospravedlnění práv menšin.

2 Ze stejného důvodu je následující analýza omezena na formální úroveň zákonů státu a jeho politik. Tím není popíráno, že „nacionalistické“ nebo „rasistické“ uvažování nebo jednání nemůže být nepř́jemně útočné $\mathrm{v}$ jiných sektorech společnosti, dokonce i mezi (některými) elitami státu. Avšak takové uvažování nebo jednání zůstává nutně skryté a zcela ve shodě $\mathrm{s}$ formální fasádou „nediskriminace“. V tomto minimálním významu je formální fasáda nediskriminace „skutečná ve svých důsledcích“" a nemůže být zcela odmítnuta jako pouhá propaganda nebo předstírání. Pokud je však vzneseno obvinění z předstírání, nutně se vystavuje protiútoku vytvoření konspirace, která se vymyká reálným rozměrům.

3 Přestože je formálně mimo dosah Mezinárodní konvence OSN o Odstranění všech forem rasové diskriminace (v článku 1.3), podléhá oblast imigrace a občanství některým omezením mezinárodního práva (viz Goodwin-Gill 1978: 5. kapitola). 
obtíže, které vyvstanou lpěním na paradigmatu „vlastnictvi““ či „národního státu“. V druhé části se $\mathrm{k}$ těmto námitkám stavím kladně, odhalujíc některé univerzalistické a nediskriminační znaky současných politik imigrace a občanství v dnešních západních státech. Jak ukazuji ve třetí a závěrečné části, národní státy budou samozřejmě nadále existovat, avšak národní partikularismus již nemůže být vynucován skrze jejich politiky členství. V míře, v jaké se odkazy na národní prvky $\mathrm{v}$ těchto politikách stále objevují, jeví se tyto politiky pouze lokálními verzemi liberálně demokratického přesvědčení o rovnosti a právech jedince.

\section{Národní stát a jeho exkluze}

Andreas Wimmer (2002) se znovu vypořádává s paradoxem politické modernity, kdy univerzální principy demokracie a občanství vznikaly pouze v partikulárním prostředí, za vyloučení všech, kteří nesdíleli jisté etnické nebo národní znaky: „Moderní principy zahrnutí jsou úzce propojené s etnickými a národními formami vyloučeni““ (2002: 1). Stržení vertikálních nerovností, formálně vepsaných mezi feudální stavy a vrstvy, se uskutečnilo za cenu vztyčení nových horizontálních nerovností mezi vnitřně homogenními etnickými skupinami a národy, z nichž každý usiluje o výlučné propojení se státem za vyloučení všech ostatních, kteří jsou na základě těchto připsaných označení považováni za nepřináležející ke státu. Podle Wimmera je novým zhoubným pojmem, vzniknuvším kombinací nacionalismu a demokracie, „vlastnictvi“" státu partikulárním národem nebo etnickou skupinou, jež činí etnický konflikt, xenofobii a rasismus ,integrální součástí“ moderních národních států (2002: 5).

Přestože Wimmer nahliží na pojem „vlastnictvi“ jako na univerzální pojem politické modernity, rozlišuje mezi dvěma cestami vedoucími $\mathrm{k}$ takové modernitě. První cestou je ,,politizace etnické př́slušnosti“, $v$ níž jedna etnická skupina stát monopolizuje, ale zároveň se jí nedaří zevšeobecnit svůj „etnický““ otisk do „národního“ otisku, a tak uvízne v etnickém klientelismu a zvýhodňování. $\mathrm{V}$ tomto prípadě, který je pravděpodobně charakteristický pro většinu méně rozvinutých nezápadních společností, je tento tlak na exkluzi nasměrován k potlačení nároků vnitřních etnických soupeřu. Druhou cestou je „plná nacionalizace státu a společnosti“, která nastává tehdy, pokud jsou stát i společnost silní, a má za následek úplnou národnostní homogenizace společnosti. $\mathrm{V}$ tomto prípadě, charakteristickém pro rozvinutý Západ, je tlak na exkluzi stále př́tomen, ale je nasměrován na vnějši „,cizince“ a ,imigranty“.

Jedná se o poněkud neumělou teorii politické modernizace (co například Kanada, Belgie či Španělsko?) a Wimmer vzápětí sám připouští, že jeho zájem je zaměřen méně na přičiny a vzájemné srovnání a spíše na obecně použitelné důsledky toho, co nazývá „,model národního státu“: nástup „nových forem exkluze založených na etnicko-národnostních principech“ (2002: 81). Jeho hlavním tvrzením je, že tyto „etnicko-národnostni““ exkluze jsou v etnických a nacionálních variantách politické modernizace „strukturálně obdobné“ (2002: 268): „Osud tzv. failií Kurdů v Iráku, kteří byli v 70. letech 20. století zbaveni iráckého občanství a vyhnáni do Iránu..., je podobný nejisté právní situaci imigrantů v plně nacionalizovaných státech““ (2002: 222).

Zatímco byl zjevně vytvořen s cílem provokovat, tento antropologický pohled založený na „pohledu z odstupu“ stírá některá základní rozlišení, bez nichž se jen stěží obejdeme. Jedním z těchto rozlišení je rozlišování mezi různými misty exkluze, vnitřními nebo vnějšími; druhým je rozlišování mezi způsoby exkluze, exkluzí skupinovou či individuální. S ohledem na místo 
exkluze probíhá exkluze osoby, která se snaží začlenit se do státu (vnější exkluze), na zcela jiné úrovni než exkluze někoho, kdo již ve státě pobývá a nemá jiný stát, u kterého by hledal ochranu (vnitřní exkluze); rozdíl je přinejmenším v tom, že první je reaktivní, zatímco druhá je aktivní. ${ }^{4}$ „Diskriminaci“ v plném smyslu slova představuje pouze aktivní exkluze, a to tím, že odpírá někomu základní ,„právo na místo“ (Walzer 1983) na základě vrtkavého připsání členství ve skupině. ${ }^{5}$

S ohledem na zpưsob exkluze fungují pouze některé exkluze na základě etnické př́íslušnosti, národního původu nebo rasy a následně - v současném diskurzu o minoritách a lidských právech - mohou být označeny jako „diskriminační“. Zjevným př́kladem je asijská exkluze, která byla součástí imigračních politik před šedesátými lety 20 . století ve státech obsazených anglicky mluvícími osadníky. V návaznosti na přelomové období v oblasti lidských práv v USA v 60. letech 20. století a na celosvětové posílení kultury lidských práv byly kolektivní a připsané zpo̊soby exkluze nahrazeny individuálními způsoby exkluze, založenými na (nedostatečných) rodinných vazbách a dovednostech. Politiky imigrace (stejně jako občanství) se staly explicitně ,nediskriminačními““ ${ }^{6}$ Existuje základní rozdíl mezi bezpodmínečným skupinovým a individuálním vyloučením, a tím, že obě formy propojíme, mnoho nezískáme.

Na pozadí tohoto propojení je problematické položit rovnítko mezi exkluzi jako takovou a diskriminaci podle následujícího sylogismu vštěpovaného ,zdravým rozumem“: politika imigrace (a občanství) je vylučující, exkluze nutně znamená rozlišování a takové politiky tedy následně nemohou nic jiného než ,diskriminovat“. V pojmech politických důsledků má tento sylogismus Janusovu tvář: může přinést bud' odmítnutí, nebo odsouhlasení jakékoli imigrační politiky. Cesta k utopii bez hranic pro některé jedince může být snadno přetvořena do hyper-realistické obrany diskriminace. Podle formulace tajemného kritika asijské imigrace do Austrálie Goffrey Blaineyho (1984: 162) imigrační politika z definice „diskriminuje“ - tak proč selektivně neomezit vstup Asiatů, a navrátit tak Austrálii bílým Australanům?

$4 \quad$ Poznamenejme, že vnějši exkluze je srovnatelná s vnitřní exkluzí vzhledem k potenciálním škodám, které může přivodit jedinci. Exkluze uprchlíků byla zařazena pod přísnější právní omezení, v pojmech mezinárodního režimu uprchlíků v principu „nezahnání“, nebo dokonce v některých evropských státech (jako Francie či Německo) pod ústavní omezení. Avšak ústavní omezení byla zmírněna nebo zrušena v reakci na masivní nárůst žádostí o azyl na konci 80. let 20. století.

5 Tento způsob argumentace je v souladu s definicí „,rasové diskriminace“ v Mezinárodní konvenci o odstranění všech forem rasové diskriminace OSN z roku 1966. V článku 1.1 tato konvence definuje „,rasovou diskriminaci“ ,jako rozlišování, exkluzi, omezování nebo upřednostňování na základě rasy, barvy pleti, národního nebo etnického původu, která má za cíl nebo za důsledek zrušení nebo oslabení uznání, požívání nebo uplatňování lidských práv a základních svobod na základě rovného zacházení“. Následující pododstavec (1.2) z rovného zacházení vylučuje všechny „rozdíly, exkluze, omezení nebo upřednostňování... mezi občany a cizími státními př́islušníky“.

6 K tématu zemí osídlených anglicky mluvícími osadníky viz Joppke (2005b). Připust’me, že v Evropě je rétorika „nediskriminace“ méně výrazná. Avšak kdykoli byla vznesena obvinění z etnické diskriminace proti některému z evropských států, příslušná vláda existenci takové diskriminace vždy popřela. Výmluvným př́kladem je diskuse okolo klauzule o ,patriotismu“ Imigračního zákona v Británii z roku 1971, která byla oponenty (Labour Party a aktivisty z celého světa) napadána jako rasově diskriminační, avšak která byla vládou Toryů hájena na základě uznání neetnických termínů „rodinných vztahů““. K této diskusi viz Joppke (2004b). 
Je zajímavé, že Wimmer si správně všímá toho, že očividný „rasismus a xenofobie“ jsou v současných západních společnostech přisuzovány „mobilitně sestupujícím“, zatímco „stát... se zjevně zdráhá jednat“ (2002: 215). Avšak Wimmer již není schopen své tvrzení teoreticky zdůvodnit. Naopak rigidita jeho „,modelu národního státu“ ho vede ke zlehčování či zkreslování univerzalismu na úrovni národního modelu. Obzvláště zjevné to je v jeho rozboru imigrační politiky ve Švýcarsku, která má být př́ikladem vnějškově orientované „exkluze ve znacionalizovaných státech“. Jak vyžaduje „,model národního státu“, krouží kapitola okolo „systematické diskriminace mezi cizinci a státními příslušníky, vepsané do zákonů o občanství a zvláště do institucionální mašinerie, která kontroluje a omezuje migrační př́livy“ (2002: 222). Návrh, který se zjevně nabízí, zní, že již právní rozlišování mezi občany a nelegálními přistěhovalci představuje „diskriminaci“. Ale jaké označení bychom tedy měli zvolit pro vrtošivé popření práv rodiny a práv na svobodnou volbu pobytu a zaměstnání, které byly znakem původního režimu „hostujících pracovníkư‘? S ohledem na režim hostujících pracovníků Wimmer uznává, že tento byl následně nahrazen režimem liberálnějším, který status imigrantů v mnoha ohledech přiblížil statusu občanů. Tuto změnu není možné vysvětlit v rámci ,modelu národního státu“ a sám Wimmer vzápětí upouští od dalšího promýšlení této proměny završením švýcarského příběhu návratem $\mathrm{k}$, restriktivní politice“ v roce 1970. Bez povšimnutí tak přechází fakt, že politika kvót z roku 1970 omezuje pouze počet imigrantů, a je tedy méně destruktivní než dřívější politika, která nově příchozím upírala základní rodinná nebo socio-ekonomická práva. Ve skutečnosti bylo striktní omezení počtu př́íchozích možná cenou za vnitřní začlenění hostujících pracovníků, kteří se stali imigranty. To naznačuje i sám Wimmer (2002: 262): „Tato částečná integrace, která následovala dialektiku inkluze a exkluze, šla ruku v ruce s dalším omezením př́istupu na státní území. Postupně byl zaveden velmi přísný systém imigračních kvót, kontrolovaných státem.“ Naopak pokud uzavření se před další imigrací bylo výsledkem rostoucí snahy o vnitřní inkluzi, pak touha být začleňující nemohla být motivována pouze „rostoucím soutěžením“ o migrační pracovníky, jak Wimmer podivně jedním dechem prohlašuje (2002: 262) - obě tvrzení jsou logicky neslučitelná.

V celém textu je systematicky opouštěna „liberální“ logika (poháněná tlakem soudů či občanské společnosti), jež mohla donutit švýcarský stát k opuštění původní politiky hostujících pracovníků (tzv. ,gastarbeiterů“), jak tomu bylo ve všech ostatních evropských společnostech, které prodělaly ve stejné době podobnou zkušenost s hostujícími pracovníky (viz Guiraudon 2000). Wimmer (2002: 2 a dál) poznamenává na samém začátku svého pojednání, že od 70. let 20. století se ,většina západních společností... navrátila k dřívější, liberálnější podobě definice těch, kteří přináleží“, ale uhýbá před zjevným problémem, který tato skutečnost přináší pro jeho vylučující ,model národního státu“.

V kontrastu s Wimmerovým antropologickým a př́liš zevšeobecňujícím představením vylučujících „stínů modernity“ politolog Anthony Marx (2002, 2003), který pojednává o stejném tématu ,národního státu a jeho vyloučeních“ (podobně jako Wimmer, za udivujícího vzájemného přehlížení), nahlíží přesněji na prríčiny, podoby a načasování národní exkluze. Zatímco potenciál k exkluzi je nacionalismu vnitřně vlastní, jak je to shrnuto v Yeatsově výroku ,je více podstaty v našem nepřátelství než v naší lásce“ (citováno v Marx, 2003: 29), bývá jasně vyjádřen pouze ve specifických situacích - zvláště tehdy, pokud se elity státu snaží zacelit vnitřní rozepře selektivním vyloučením třetí strany. Marx zmiňuje možnost vnějších exkluzí pouze stručně a celá jeho pozornost je příhodně věnována stěžejnímu bodu, jímž je exkluze vnitřni skupiny. 
Pokud přehlédneme jím uváděné př́klady, které sahají od náboženských pronásledování v raně moderní Evropě až $\mathrm{k}$ jihoafrickému apartheidu, všimneme si, že se z velké části odehrávají zejména $\mathrm{v}$ době utváření států a jsou namířeny $\mathrm{k}$ odstranění nebo alespoň ke zmírnění a potlačení historické paměti vnitřní logikou demokracie a „občanské“ státnosti, jež je také ustavována ve vznikajícím národním státě. Zejména jeho analýza „původu exkluze nacionalismu“ v raně moderním Španělsku, Anglii a Francii (Marx 2003) je vedena politickým poselstvím, podle nějž údajně „občanský“ nacionalismus Západu nebyl o nic méně brutální, sektářský nebo vylučující než „etnický“ nacionalismus Východu. Avšak text obsahuje také poselství, že nacionalismus zdaleka není stálým „stínem modernity“, nýbrž že se vyčerpává svými vlastními úspěchy a je vyvažován jinými principy, zejména liberální demokracií a občansko-územní státností.

\section{Od skupinové k individuální exkluzi v liberálním státě}

Stát „,vlastněný“ určitým národem, nebo naopak státními elitami, které aktivně strukturují společnost $\mathrm{k}$ obrazu jistého národa, je adekvátním paradigmatem pro politiky imigrace a občanství prosazované klasickým národním státem od pozdního 19. do raného 20. století. Z vnitrostátního hlediska se jednalo o stát „rozvinuté modernity“ (Scott 1998), zaměřený na vytvoření „dokonale čitelné populace s registrovanými, jedinečnými jmény a adresami provázanými se sídly; vykonávajícími identifikovatelné zaměstnání; a jejichž všechny transakce jsou zdokumentovány podle naplánovaného vzorce a v úředním jazyce“" (1998: 82). Z mezinárodního hlediska se jednalo o imperialistický stát, uzavřený do anarchistického a v konečném výsledku násilného boje o prežití vedeného proti ostatním státům. Nacionalismus a rasismus poskytly vhodné fráze sloužící dvěma cílům, vytvoření čitelných a zároveň bojovných společností, nebot' ličć kolektivity jako útvary tvořené identickými, navzájem podobnými jednotkami, zároveň však též jako útvary ostře oddělené od ostatních kolektivit. Podle př́hodného Taguieffova vyjádření (2001: 202 a dále), v klasických národních státech byly kolektivy individualizovány, zatímco jedinci byli kolektivizováni. Politiky imigrace a občanství tak byly ve službách reprodukce vnitřně homogenních, avšak vnějškově jasně ohraničených kolektivit, čehož bylo docíleno trríděním nově př́chozích na základě jejich etnické př́islušnosti, rasy nebo národního původu. Toto bylo jak archaické, odsunujíce jedince ke statusu kopií nebo navzájem si podobných jednotek uvnitř připsaných skupin, a zároveň v přehnané míře moderní, hnané plánem racionálně řídit společnost shora. „Vědecký plán na udržení Ameriky americkou“ (Warner Parker, 1924: 740) - tento dobový popis imigrační politiky USA roku 1924, založené na kvótách „národního původu“, vyjadřuje vhodně dualitu oné modernisticko-archaické politiky.

At’ už přivodilo vznik , liberálního státu“ cokoli (což je mimo rozsah této diskuse) ${ }^{7}$, je jeho znakem potlačení partikularistického budování národa ve prospěch univerzálních principů lidských práv. Status quo ante je drasticky shrnut ve vzpomínce osvětimského vězně Primo Leviho na setkání s Dr. Pannwitzem, který si tohoto vězně vyhlédl pro možnou službu v táboře, jež by

7 Výčet aktérů a mechanismů, které přivedl k životu „liberální stát“, by přesáhl omezený rozsah tohoto článku. Namísto toho beru existenci liberálního státu za danou a nahlížím pouze na některé jeho důsledky - nebo naopak tyto důsledky (v politikách imigrace nebo občanství) mohou svědčit o existenci liberálního státu. 
ho ušetřila jisté smrti: „Tento pohled nebyl pohledem dvou lidí; jakoby si ho mezi skleněnou stěnou akvária vyměnily dvě bytosti, které obývají odlišné světy“ (citováno v Ignatieff 2001:3). Znakem liberálního státu je rozbití těchto nacionalistických a rasistických stěn a institucionalizování minima sdíleného lidství. Klíčovým dokumentem je Všeobecná deklarace lidských práv OSN z roku 1948, která se od té doby stala „lingua franca celosvětového morálního myšlení“ (Ignatieff 2001: 53), vnucujíce strukturální překážky v rámci toho, co státy mohou podniknout ve jménu „svého“ lidu. Jako odpověd’ na ztrátu ospravedlnění krajního nacionalismu a rasismu holocaustem se západní poválečné státy staly státy ústavními, ve kterých jsou práva většiny ohraničena principy univerzálních lidských práv, vepsaných do vnitrostátních ústav, které již nebyly omezeny na vytyčení vnitřního projektu státu, ale předepisovaly nyní hranice pro zacházení státu s jednotlivci (o Evropě viz Stone-Sweet 2000).

Fakt, že sdílená lidskost již nemůže být upřena nečlenům národní nebo etnické skupiny, která je ztotožňována se státem, zásadně proměnila význam slova „exkluze“. Toto budu diskutovat v následující části, za použití př́kladů politik imigrace a občanství.

\section{Imigrační politika}

Imigranti se zpravidla nacházejí na křižovatce vnější a vnitřní exkluze. S ohledem na vnější exkluzi jsou předmětem státní „imigrační politiky“, která upravuje prŕstup na území státu a $\mathrm{k}$ vybraným sektorům společnosti, zejména $\mathrm{k}$ trhu práce. Pokud zkoumáme vývoj imigračních politik západních států od jejich prvních systematických vypracování na počátku 20. století, všimneme si jejich vzrůstajícího univerzalismu a snižujícího se rozsahu připsaných skupinových rozdílů $\mathrm{v}$ těchto politikách. Kdysi bylo jednoznačně ustaveno, že imigranti jistého etnického nebo národního původu mají být upřednostňováni před jinými, a imigranti jistých nežádoucích „ras“ byli dokonce vyloučeni úplně. Ospravedlněním byl odkaz na jejich odlišnou schopnost „asimilace“ do prijímající společnosti. Jde o překvapivý vývoj, kdy tyto připsané skupinové rozdíly teoreticky vymizely $\mathrm{z}$ imigračních politik, jež obecně přešly $\mathrm{k}$ hodnocení na základě individuálních kritérií dovedností a rodinných vztahů. Jediným ospravedlnitelným skupinovým rozlišením, které přetrvává, je rozlišování mezi „občany“, kteří mají právo vstoupit a nemohou být vyhoštěni, a „cizími státními př́slušníky“, kteři žádné z těchto práv nemají a kteří jou předmětem zájmu imigračních a cizineckých státních politik.

Zatímco „cizí státní příslušníci“ jsou nadále předmětem exkluze, je tato exkluze zásadně odlišná od exkluze nacionalistické či etnické. Etnická exkluze funguje na základě zvláštních skupinových charakteristik, kdy neexistuje možnost přjít z jedné skupiny do druhé. Naopak cizí státní příslušník není národnostní nebo etnickou kategorií, nýbrž kategorií formálně právní - cizí státní př́íslušník je vyloučen nikoli proto, že je členem zvláštní skupiny, ale proto, že není občanem. Status cizího státního př́slušníka je tedy vymezen záporně a reziduálně. Navíc pokud existuje možnost, že se cizí státní př́slušník stane občanem nejprve na základě pobytu a později skrze „naturalizaci“ $v$ novém státě, jedná se o individuální a nikoli skupinové rozlišení. Dokonce i když mají státy formální svobodu odepřít vstup cizímu státnímu př́slušníkovi, mezinárodní právo zakazuje odmítnutí cizího státního př́slušníka na vrtkavém základě etnického či rasového původu - pravidlo nediskriminace je uplatňováno dokonce i tam, kde se zdá, že státní suverenita dosahuje svého vrcholu (viz Goodwin-Gill 1978: kapitola 5). 
Samozřejmě že stejná nediskriminační pravidla upravují v současném liberálním státě právní přechod od vstupu přes pobyt až k občanství; až na výjimku úzce vymezených „etnických migrantư“ (Joppke 2005a) by tak mělo být překročení hranic stejné pro všechny cizí státní př́slušníky, bez ohledu na jejich etnický, rasový nebo národní původ.

Jediné omezení, které má současný liberální stát k dispozici, je omezení počtu. Zatímco veřejný odpor proti imigraci je zcela jistě podmíněn tím, $k d o$ migruje, vstřícná reakce liberálního státu může spočívat pouze v uzavření se veškeré imigraci, nikdy však v zastavení této partikulární imigrace. Všimněme si, že ačkoli pozastavení náboru do západoevropských států následující po první ropné krizi v roce 1973 nezohledňovalo státní př́slušnost, a to i přes zjevnou převahu imigrantů jistého národnostního a regionálního původu (Turci v Německu a Švýcarsku, Alžířané či Severoafričané ve Francii), bylo jablkem sváru.

Restriktivní opatření mohou být specifická pro určité státy či skupiny pouze jako výsledek zvláštního režimu nebo za úzce vymezených podmínek (zejména pokud je existence těchto podmínek před veřejností utajena). Př́kladem zvláštního režimu jsou bilaterální dohody s vysílajícími státy, které samozřejmě umožňují cílenou inkluzi nebo exkluzi svých občanů. Např́klad mezinárodní právní status alžírských imigrantů poskytl konzervativnímu francouzskému prezidentovi príležitost se jich na konci 70. let 20. století zbavit jednoduše neobnovením jejich zvláštního desetiletého práva pobytu, jež bylo založeno na bilaterální smlouvě z roku 1968 a jež tedy bylo mimo kompetence vnitrostátního imigračního zákona (který od svého zavedení v roce 1945 úmyslně opomíjel rozdíly ve státní př́íslušnosti). Tento zákon nápadně selhal kvůli „tradiční mobilizaci“ církví, odborářských svazů, levicových stran a Nejvyššího správního soudu (Weil 1995: 99) - přestože existovala formální možnost diskriminačního opatření, selhala z důvodů značných nerovností, které by tato opatření vytvořila.

Druhý zvláštní režim představuje manipulace s neetnickými kategoriemi výběru na základě dovedností a rodinných vztahů s cílem dosáhnout žádaného etnického výsledku. Zvláště v zemích anglicky mluvících osadníků bylo jednoznačné upřednostňování kvalifikovaných imigrantů po dlouhou dobu považováno za skryté upřednostňování evropských imigrantů. A naopak kritika príijímání osob na základě rodinných vztahů byla brána za odmítnutí neevropské imigrace. Avšak proměňující se demografický profil současné imigrace, zvláště nárůst kvalifikace u neevropských imigrantů, odstranil důvod uchylovat se $\mathrm{k}$ úskočnému etnickému výběru (a jeho kontrole; viz Joppke, 2005b).

Kdekoli přesto dochází k etnickému výběru, je jeho minimální podmínkou, aby zůstal utajen před veřejností, což je často možné skrze vyčerpávající administrativní zdrženlivost, kterou každé zákonodárství - a u imigrace zvláště - ponechává státu při jeho uplatňování. Toto je očividně způsob, jakým se západnímu Německu, ve kterém byl jakýkoli etnický nebo nacistický diskurz kvůli zkušenosti s nacismem formálně postaven mimo zákon, podařilo v populaci hostujících pracovníků v 50. a 60. letech 20. století snížit prítomnost tzv. „AfroAsiatư“ na minimum (viz poučná Schönwälderova studie 2004).

Jestliže posuzujeme imigrační politiky současných západních států, rozpoznáme, že již nejsou ve službách reprodukce jisté národnosti. Pokud takové státy umožňují nebo nabízejí imigraci, nevyhnutelně tím riskují etnickou či rasovou proměnu svých společností. Nacionalistické a xenofobní tendence př́tomné v těchto společnostech již nejsou ve sku- 
tečnosti institucionalizovány ve státních politikách imigrace (jako tomu bylo na počátku 20 . století), ale jsou nyní mimořádnou nebo proti-institucionální odpovědí politikám, které jsou nevyhnutelně nediskriminační, pokud jde o etnický, národnostní či rasový původ migrantů.

\section{Politika občanství}

Po překonání obtíží spojených se vstupem na území (tj. potenciální vnější exkluze) se imigranti stávají možnými objekty vnitřní exkluze. Avšak možnosti pro jejich vnitřní exkluzi jsou ještě více omezené než pro exkluzi vnější, která nadále zůstává legitimní pod záštitou státních imigračních a občanských politik. Nyní do hry vstupuje demokratická logika, podle které se imigranti stávají spolupracujícími členy společnosti, jimž je stát, pod jehož střechu přišli pobývat, povinován stejným zacházením a na jehož ochraně jsou nyní závislí (viz Rubio-Marin 2000). Tento fakt se stal předmětem skutečné ústavní revoluce např́ič západními státy. V klasickém národním státě dokonce i dobrovolně najímaní migranti zůstávali především členy vzájemně neslučitelných a často ponižovaných kolektivit; zůstávali vyloučeni ze základního sociálního zabezpečení a péče; jejich celá existence $\mathrm{v}$ príijímajícím státě byla nejistá a byla vystavena riziku nečekaného vyhoštění (o vyhoštění Severoafričanů v meziválečné Francii viz Lewis 2000; o vyhoštění Poláků z Wilhelmovského Německa viz Bade 1984: 462-71).

Poválečný liberální stát zaručuje lidská práva ústavou, v níž jsou lidská práva nejčastěji formulována odděleně od statusu občanství, avšak omezuje rozmary výkonné moci, a tak se ve skutečnosti dlouhodobě usazení imigranti přiblížili občanům. Toto přibližení bylo především výsledkem ústavní politiky nezávislých soudů, které se dnes považují za ochránce jedinců oproti př́lišnému dosahu státní moci (viz Joppke 2001; pro alternativní náhled zdůrazňující faktory globální úrovně viz Soysal 1994).

Měnící se ontologie společnosti byla tímto vývojem jak doprovázena, tak také poháněna: společnost již nevystupuje jako kolektivní osobnost, uvíznuvší v boji o přežití s ostatními kolektivními osobnostmi, ale jako místo obchodu a spolupráce mezi svobodnými a rovnými jedinci, pro které je jejich vlastní národnost $\mathrm{v}$ konečném důsledku nedůležitá. Kanonicky byl tento názor vyjádřen Nejvyšším soudem Spojených států v případu vyloučení Číňanů z roku 1889:

Pokud [Kongres] považuje přítomnost cizinců jiné rasy odmítající asimilaci do naší společnosti za hrozbu míru a bezpečnosti, jejich exkluze nebude strpěna... a je nezvratná s výkonem soudní moci. ${ }^{8}$

Druhý, novější názor byl podobně vyjádřen Nejvyšším soudem Spojených států ve slavném rozhodnutí Graham vs. Richardson o 82 let později (který postavil mimo zákon diskriminace prováděné vládami jednotlivých států federace na základě cizí státní př́slušnosti): „Cizí státní př́slušníci, podobně jako naši občané, platí daně a mohou být povoláni do služby v branných složkách... [Cizí státní př́ślušníci] mohou po mnoho let ve státě žít, pracovat a prispívat k jeho ekonomickému růstu.“9

$8 \quad$ Chae Chan Ping vs. Spojené státy, 130 USA 581 (1889), s. 606.

9 Graham vs. Richardson, 403 USA 365 (1971), s. 376. 
Tendence $\mathrm{k}$ univerzalismu a $\mathrm{k}$ individuální, v protikladu ke skupinově založené, inkluzi či exkluzi je nejvíce viditelná v př́istupu k občanství, a tedy v samotné „politice občanstvi“". Anthony Marx (2002: 113 a dále) tajemně poznamenal, že státu vlastní potenciál pro exkluzi může být někdy orientován externě (namísto interně), a v tomto prípadě se vztahuje na „cizince“, a to v podobě „,selektivního občanství“. Bohužel však nevysvětlil význam slova „selektivní“. Celkem vzato však v této oblasti existují opět dva způsoby „selektivity“: skupinová selektivita, v níž připsané charakteristiky (na kterých jedinec nic nemůže změnit) bud’ otevírají, nebo zavírají dveře k občanství; a individuální selektivita, podle které stát neumožňuje získání občanství nově príchozím, je však alespoň nucen být $\mathrm{v}$ tomto ohledu stejně vylučující ke každému bez rozdílu.

Je zajímavé, že se oba způsoby „selektivity“ v oblasti občanství významně uvolnily. Skupinová selektivita bud' zcela vymizela, tak jako rasová exkluze, která poskvrňovala pravidla americké naturalizace až do počátku 50. let 20. století; nebo přetrvávají ve velmi zvláštních, pozitivně diskriminačních podobách, jako je samozřejmé přidělení občanství Židům v Izraeli nebo Němcům v Německu. Důležitou součástí těchto pozitivně-diskriminační selektivit je, že nevyčerpávají možnosti získání izraelského nebo německého občanství, ale jsou dodatečnými procesy naturalizace, které jsou stejnou měrou př́stupné komukoli, nezávisle na jeho původu.

S ohledem na individuální selektivitu je velmi zajímavý nejnovější vývoj, přinášející obrat v získávání občanství postupující od situace, kdy je státu přenechán volný prostor pro uvážení, až k právu na straně cizího státního př́slušníka (jež je definováno jako délka pobytu nebo narození na jistém území), s tím, že stát opouští explicitně dané (a individuálně ověřované) požadavky na asimilaci v této oblasti. Zejména s ohledem na naturalizaci je objevení se „práva“ na občanství pozoruhodným vývojem, protože v této oblasti dosahovalo jednání státu na základě uvážení svého vrcholu. Naturalizace byla tradičně ponechávána na uvážení nejen $\mathrm{v}$ tom smyslu, že zákonodárce měl svobodu utvářet př́slušná pravidla podle toho, jak uznal za vhodné, ale také v daleko silnějším významu, kdy i poté, co byly ze strany žadatele splněny všechny formální požadavky pro naturalizaci, mohl stát stále říci „ne“. Například podle starých německých administrativních pravidel byl brán v úvahu jen „veřejný zájem“ státu a nikdy osobní zájem kandidáta na občanství. Na počátku 90. let 20. století byla tato naturalizace podle uvážení státu v př́ípadě cizích státních prŕíslušníků splňujících jisté požadavky na pobyt (a další požadavky) nahrazena „právem“ na získání občanství. Kulturní „,asimilace“, jakožto předpoklad k získání občanství, byla explicitně odmítnuta a nahrazena měkčím požadavkem na „integraci“ (Hailbronner a Renner 2001: 659). Po reformě zákona o občanství z roku 1999 byla tato „integrace“ definována „dostatečnou znalostí německého jazyka“, stejně jako písemným stvrzením ,závazku k liberálnímu demokratickému řádu“ německého státu.

Nezaměňujme však rozlišování mezi skupinovou a individuální selektivitou s rozlišením jus sanguinis (zákon krve) a jus soli (zákon půdy) vztahujícím se k občanství při narození, které bylo od vlivné Brubakerovy (1992) práce obecně bráno za hlavní rozlišení mezi způsoby „uzavírání se“ moderního národního státu. Jus sanguinis v sobě takovou skupinovou selektivitu nezahrnuje. Je proto nesprávné definovat jus sanguinis jako „systém, díky kterému se člověk stane občanem tím, že se narodí někomu z etnické skupiny, která v jisté zemi převažuje (např́- 
klad tím, že se narodí etnickému Němci v Německu)“ (Fetzer 2000: 218). To sice odpovídá stereotypu, podle kterého je etnické občanství „rasistické“ (napřr. Hampton 1995), ale již to neodpovídá právní skutečnosti. Už za platnosti Reichs- und Staatsangehörigkeitsgesetz z roku 1913 se člověk stal německým občanem při narození jednoduše tím, že se narozdil německému rodiči, bez ohledu na jeho „etnický původ“. Německý zákon o občanství nebyl nikdy založen na právní definici německé etnické př́slušnosti (viz Silagi 1999:79-83). Jakkoli to tehdy bylo nesnadné, vždy existovala možnost získat německé občanství naturalizací. Jak vhodně poznamenává Dieter Gosenwinkel (2001: 236), pokud tato možnost existovala, ona „krev“ v principu ,jus sanguinis “ byla formální a instrumentální, nikoli substanciální. Tím však nechceme popř́it, že německé občanství bylo v minulosti spojeno s inkluzí a exkluzí na základě skupinové př́slušnosti. Nebylo však vůbec propojeno s občanstvím via jus sanguinis, ale s administrativním uskutečněním naturalizace (které $\mathrm{v}$ meziválečném období upřednostňovalo německý původ žadatelů před ruskými a vylučovalo východní Židy (viz Gosenwinkel 2001: kapitola 7).

Položení rovnítka mezi občanství jus sanguinis a „rasistickou“ skupinovou exkluzi také opomíjí to, že od dob Francouzské revoluce odpovídá jus sanguinis veskrze modernímu pojetí členství, podle kterého je členství právo jedince, které je předáváno - podobně jako rodné př́ijmení - následující generaci; podle tohoto chápání již jedinec není nahlížen jako vlastnictví feudálního pána, který vlastnil všechny plody své země, včetně lidí - tento feudální význam vlastnictví půdy a lidí stál u zrodu tradice jus soli. V odezvě na migrační vlny konce 19 . a průběhu 20. století však došlo $\mathrm{k}$ přehodnocení relativní modernosti obou způsobů přiznávání občanství při narození, nejprve ve Francii v roce 1889 a s (předčasným) ukončením v Německu v roce 1999, kdy jus soli převažuje nad jus sanguinis. Většina evropských států nyní doplňuje své tradiční zákony občanství jus sanguinis prvky jus soli (viz Weil 2001). Jeden autor zabývající se tématem práva (Orentlicher, 1998) dokonce zašel tak daleko, že prohlásil občanství na základě území upřednostňovanou formou občanství v mezinárodním právu. Následkem toho se občanství stalo méně vylučujícím a zvenku více př́stupným. V kombinaci s nediskriminačními přístupy a postupy, které umožňují udělení trvalého pobytu, občanství podle jus soli zaručuje, že občanství bude automaticky (nebo později volbou) uděleno komukoli, bez ohledu na jeho etnický, rasový nebo národní původ. Výše uvedené musí mít za následek oddělení občanstva od konkrétního národa nebo etnické skupiny a oslabení celého konstruktu „vlastnictvi““ státu jistou skupinou.

\section{Oddělení státu a národa}

Obraz, který se vynořuje, je obrazem oddělení státu a národa v politikách členství v liberálním státě. Státy jsou zjevně i nadále „národními státy“, identifikovatelnými podle jména jako jedinci, ztělesňující jedinečnou historii a pospolitost. Státy se však stávají široce otevřenými nově příchozím, kteří už nemohou být začleněni nebo vyloučeni na základě připsaných skupinových charakteristik, ale pouze jako jedinci. Liberální a nediskriminační normy spolu s normami lidských práv zabrzdily partikularistické možnosti „budování národa“ státem. Politiky členství mohou být stále formálně zaměřené na „budování národa“, ale jen v obecně použitelném smyslu vytvoření neetnických, liberálně-demokratických kolektivit, které však nejsou odlišné od těch ostatních. Právě v těchto politikách, které jsou zaměřené na stř̌ežení hranic určitých společností, byla uplat- 
ňována většina partikularismů (přinejmenším rasové, etnické nebo národnostní povahy). Pokud současné západní národní státy vylučují, činí tak individuálním a nediskriminujícím způsobem, který nemůže být vysvětlen kolektivistickým jazykem etnické př́islušnosti a nacionalismu.

Jeden ze způsobů, jak objasnit návrat od kolektivistických forem inkluze a exkluze k formám individuálním, spočívá v systémově-teoretických pojmech (viz Luhmann 1982). Národní stát byl nakažen univerzalistickou logikou, která vládne v diferencovaných sférách moderní společnosti. V segmentované diferenciaci tradiční společnosti přináleželi jedinci ke společnosti přímo svým začleněním, jako celé bytosti spadající do specifického klanu nebo segmentu. Naopak funkční diferenciace moderní společnosti vede $\mathrm{k}$ dvojímu důsledku vyloučení jedince $\mathrm{z}$ celku společnosti a jeho začlenění pouze v určitých ohledech, avšak jako „svobodného a rovného“ ve všech diferencovaných sférách, od vzdělání k právu, politickému zř́zení a ekonomice. Klasický národní stát dlouho představoval výjimku z této logiky, vylučoval a začleňoval jedince jako celé osobnosti, a dokonce se snažil vytyčit umělé národní hranice okolo jednotlivých diferencovaných sfér společnosti, jakou představuje „,národní ekonomie“ stárnoucí populace. ${ }^{10}$ Přesně tento důsledek globalizačních a transnacionalizačních procesů osvobodil společenské subsystémy od jejich starých národních omezení a umožnil jim propojit se s jejich ekvivalenty za hranicemi (do těchto procesů jsou dokonce zapojeny i vládní agentury; viz Slaughter 2004). Normy nediskriminace a lidských práv uštědřily velkou ránu poslední (přestože zároveň první) baště nacionalismu. Tváří v tvář vzrůstající pluralizované a autonomní společnosti vymazává současný stát množství etnických a kulturních nacionalismů ze svých zákonů a politik a vydává se směrem $\mathrm{k}$,,veřejné neutralitě“, odpovídající představám liberálních teoretiků a teoretiček (například Dworkin 1978).

Vnitřní liberalizace poválečných západních společností, tj. rozpouštění formálních (a často také substanciálních) nerovností, které se ustavují jako důsledek rasy, genderu, náboženství a třídy, ovlivnila dokonce způsob nakládání s nejtrvalejší a nejlegitimnější ze všech skupinových distinkcí, distinkcí mezi „občanem“a „cizím státním př́islušníkem“. Pokud bylo „občanství" přesvědčením, které mělo překonat, nebo alespoň zkrotit tato stará skupinová rozdělení, nemohl být z obroušení těchto ostrých hran vyjmut ani status cizího státního příslušníka. Je to paradoxní, nebot’ existence „občana“ je postavena na předpokladu (rozdílně situovaného) „cizího státního příslušníka“. Nakažlivá logika, která za výše uvedeným stojí, je nepřekonatelným způsobem vyjádřena v rozhodnutí Nejvyššího soudu Spojených států (výše citovaný př́pad Graham vs. Richardson), které prohlásilo diskriminaci na úrovni jednotlivých států na základě cizí státní příslušnosti za ,podezřelou klasifikaci“, podobnou rase nebo genderu, protože na cizí státní příslušníky bylo nahlíženo jako na vytvářející jedince „oddělené ostrůvky menšin“" (viz Rosberg 1983).

Následně došlo k liberálnímu rozvolnění jedné z posledních spíše „segmentovaných“ než „funkčních“ forem inkluze do moderní společnosti - členství v národním státě. ${ }^{11}$ Podobně jako v př́padě mnohonásobné a pouze částečné inkluze do různých sfér společ-

10 Pro získání představy viz Weberova neblaze proslulá inaugurační přednáška na Freiburské univerzitě „Der Nationalstaat und die Volkswirtschaftspolitik“ (1895).

11 Je zajímavé, že druhou zbývající oblastí segmentované inkluze je rodina. Není proto divu, že národní prŕíslušnost byla často formulována $\mathrm{v}$ rodinných termínech (jako v Zolbergově pojmu moderních národů jako ,rodinně podobných uskupení“"). 
nosti můžeme stále častěji náležet do různých států zároveň (viz Hansen a Weil 2002); a neetnický individualismus vládne od teritoriálního vstupu až k udělení nejvyššího statku členství, které je stále častěji vyjadřováno jako právo jednotlivce dané splněním jistých podmínek splněny. Samotné vyloučení etnické př́íslušnosti a nacionalismu z formálních zákonů státu a institucí však neznamená, že tyto vymizely. Naopak etnická př́íslušnost a nacionalismus se staly neukotvenými možnostmi v jiných sektorech společnosti (jak to Wimmer empiricky potvrdil, avšak teoreticky nezohlednil, Wimmer 2002: 215). Je podezřelé, že současně došlo jednak k od-etnizování státu a k nástupu multikulturalismu na levici, jednak $\mathrm{k}$ nástupu xenofobního populismu na pravici. ${ }^{12} \mathrm{~S}$ ohledem na nástup multikulturalismu Daniel Bell již před čtvrtstoletím poznamenal, že právě tehdy, když byl státem vedený nacionalismus na Západě na ústupu, došlo k šíření „etnické př́íslušnosti“ na úrovni nižší než státní, která umožňovala kombinaci „zájmu a emocionální vazby“ (Bell 1975: 169). Dokonce i nejlepší teoretikové multikulturalismu (jako např. Kymlicka 1995) přehlédli, že multikulturní politika „uznání“ nastoupila právě tehdy, když se začaly vytrácet praktiky bezpodmínečné exkluze a vnucování kultury přistěhovalcům a etnickým menšinám; tj. právě v té době, kdy na migranty nebo etnika existovaly minimální nároky zpětně „uznat“ zvláštnosti této země. $Z$ toho vyplývá, že přinejmenším stejnou měrou, jakou byl multikulturalismus tlačen pocitovaným „utlačováním“ (Young 1990) nebo aspirací na kompenzaci za opakující se budování národa (Kymlicka 1995), byl multikulturalismus zároveň tažen vzduchoprázdnem, které nastalo po ústupu státu od etnického a nacionalistického partikularismu.

$\mathrm{Na}$ straně druhé můžeme namítat, že do té míry, do jaké nespoutaný nacionalismus vymizel ze státních politik a institucí a v níž elity hlavního proudu převzaly „proti-populistické normy“ (Freeman 1995), byl takovýto nacionalismus k dispozici politickým podnikavcům extrémní pravice. Navíc fakt, že se nástup xenofobního nacionalismu pravice mírně opožd'uje za nástupem multikulturalismu, podporuje názor, že xenofobie byla reakcí na multikulturalismus. Svébytná logika pravicového populismu, která jej odlišuje od ostatních podobných hnutí působících v minulosti, je heslovitě shrnuta v Le Penově pirátském přivlastnění levicového multikulturního sloganu droit à la difference. Přinejmenším v tomto zvláštním př́padě je současný pravicový populismus podvojnou odpovědí na od-etnizování státu $a$ „menšinovou“ odvetu etnické prŕíslušnosti, která přešla pod označení „multikulturalismus“. Pokud to mohou mít „oni“, tak proč ne „my“, národní většina, jejíž zájmy a přání již nejsou adekvátně reprezentovány liberálním státem, zbaveným své tváře a odvahy? Logickou odpovědí na „etnické upřednostňováni““, skandované (francouzskými) multikulturalisty, bylo následně ještě hlasitějši skandování „národního upřednostňování“, které se stalo hlavním sloganem Národní fronty od roku 1985 (Taguieff 2001: 171).

12 Připouštím, že následující postřeh o důsledcích od-etnizování státu pro politickou mobilizaci společnosti je spekulativní; vyjádřeno kladně, mapuji „,Zvolené př́ibuzné rysy“ mezi pozorovanými jevy, zatímco otázka kauzality zůstává nepotvrzena. Stejně tak je pravdou, že tato pozorování mohou obsahovat jádro širší empirické výzkumné agendy. 
V imigračních politikách západních států, které byly zahnány do úzkých multikulturalismem levice a xenofobním populismem pravice, došlo nedávno k občansko-nacionalistickému obratu, od vzkříšení nadlouho opuštěného pojmu ,amerikanizace“ až k revalorizaci občanství a občanské integrace v mnoha evropských státech (k amerikanizaci viz Pickus 2001; k integraci viz Joppke 2004a). Podnětem k občansko-nacionalistickému obratu je snaha ovládnout odstředivé síly pluralizující imigrantské společnosti centristickým přesvědčením, stejně jako zajistit lidem, narozeným $\mathrm{v}$ dané zemi, že jejich přirozené prostředí nebude $\mathrm{k}$ nepoznání pozměněno imigranty, kteří nemohou být zastaveni právními způsoby, což bude ještě posíleno z ekonomických a demografických důvodů.

Avšak občansko-nacionalistický obrat čelí všude stejnému dilematu: není v něm možné pojmenovat partikulárnost „,zde, a nikoli jinde“. Zatímco cílem je přizpůsobit nově příchozí „americkým“, „,holandským“ nebo „britským“ zvyklostem, skutečné vy̌řcení těchto zvyklostí vede pouze k lokálním verzím stejného liberálně-demokratického přesvědčení. Například Komise pro reformu imigrace (1997) definovala ve Spojených státech „amerikanizaci“ jako „kultivaci sdíleného závazku k americkým hodnotám svobody, demokracie a rovných př́ležitostí “ (1997: 26) společně s důrazem na „rychlé nabytí znalosti anglického jazyka“ (1997: 37) - a dokonce ani s ohledem na anglický jazyk zde nespatřujeme nic specificky amerického. V Británii se nejnovejjší posun „za multikulturalismus“, oznámený vládou Spojeného království v Bílé knize Zajištěné hranice, bezpečný ráj (2002), snaží zavázat imigranty k revalorizovanému britskému občanství a národní identitě zavedením naturalizační přísahy, př́ísněǰsími testy z anglického jazyka při naturalizaci a povinným vyučováním „občanství a demokracie“ na britských školách. Avšak pokud byla Bílá kniha nucena vyjádřit, co představuje „základní principy“ britského občanství, mohla pouze uvést: ,že respektujeme lidská práva a svobody, prosazujeme demokratické hodnoty, svědomitě dodržujeme zákony a plníme své povinnosti a závazky“ (2002: 34). Opět v tom nebylo nic specificky „britského“. Ve zvláštním sporu o „dominantní německou kulturu [Leitkultur], v roce 2000 bezúspěšně podněcovaném opozičními konzervativními stranami, bylo jediným neprocedurálním prvkem této kultury (mimo jazykových požadavkủ, bez nichž se neobejde žádný stát) zavázání se ke „křest’ansko-západní kulture“" (CDU 2000), jež zahrnovalo odkazy na ,judaismus“, ,, antickou filosofii“, ,humanismus“ a „ř́mské právo“, ale očividně nikoli na „islám“. Avšak jakkoli může být tato implicitní exkluze ožehavá, nebylo nic specificky „německého“ $v$ kulture, kterou byli imigranti žádáni sdílet; neúspěšně, jak se posléze ukázalo.

Během celého občansko-nacionalistického obratu tak zůstávají konkrétní národy, do kterých mají být imigranti socializováni, nepojmenovány. Jediným legitimním nacionalismem v západních státech je „liberální nacionalismus“, ale i toto spojení je pojmovou kontradikcí, nebot' musí být definováno v univerzalistických pojmech, jež se neliší „tady“ a „tam“. Komentátor diskuse o německé Leitkultur zachytil dilema liberálního státu následovně: „Jediným přijatelným požadavkem integrace je ve skutečnosti respekt k liberálně demokratickému řádu. Avšak pokud je zachována pouze formální svoboda, nikoli však její konkrétní obsah, co tedy zbývá z německých zvláštností?“"13 Nemožnost vnucení zvláštních „amerických“, „holandských“, „britských“ nebo „německých“ způsobů symbolizuje odloučení státu

13 Více na toto téma viz Dietrich (2000). 
a národa ve státních politikách členství, dokonce i v každém pokusu o centristické přibrzdění odstředivého multikulturalismu a obranu před zuřivým nacionalismem populistické pravice.

Jediný diskriminující potenciál inherentní občansko-nacionalistickému obratu, zvláště po teroristických útocích ve Spojených státech v září 2001, spočívá v možnosti zkomplikovat požadavky na integraci, učinit liberální stát pouze pro liberálně smýšlející. Celkově různorodá reakce západních států na teroristické útoky, kdy jejich čelní představitelé pokaždé zdůrazňovali, že restriktivní opatření jsou součástí „,války proti terorismu“, ale nejsou zamířeny na „muslimy“ jako takové, tento strach nepotvrzuje. Avšak dokonce liberalistické reductio ad absurdum, jeho proměna do podoby zapř́ísáhlého boje proti exkluzi, v sobě ukrývá odkaz na „stín modernity“, který je zcela beze vztahu k „národně-státní“ formě.

\section{Závěr: „Neustávající nárưst národního státu“}

Cíl předcházející debaty byl skromný a omezený: ukázat, jak liberálně-univerzalistická logika práv jedince a nediskriminace vpadla do oblasti vytyčování hranic a definice členství, které jsou často líčeny pod vlivem partikularistického budování národa. Současné západní státy samozřejmě pokračují v ,exkluzi“, avšak individuálním a sebe-limitujícím způsobem, který se značně liší od otevřeně diskriminačních exkluzí na úrovni skupiny, uplatňovaných v minulosti. Toto stěží představuje nový náhled: političtí sociologové globálních lidských práv obhajují tento argument již nejméně po jedno desetiletí (Soyosal 1994, Jacobson 1996). Jedná se však o natolik závažnou záležitost, že je vhodné ji znovu vyjádřit a s požadovanou detailností čelit překvapivě vytrvalému obrazu národů a nacionalismu v literatuře, obrazu „nacionální exkluze“ a „skupinového vlastnictví“ státu jako v podstatě neměnného „stínu modernity“ (Wimmer 2002).

Nejedná se však o obhajování naivní liberální utopie sebe-naplňujících se práv a zanikajících států. Naopak dokonce „,severní-západní státy“, které se staly „,skromnějšími“ a samy sebe limitují s ohledem na morální a kulturní regulace a které slábnou pod tíhou ekonomické globalizace, den ze dne narůstají, svazují, regulují a prostupují své společnosti jako nikdy předtím (Mann 1997). Jak dále Michael Mann zdůrazňuje, „neustávající nárůst“ je dokonce způsoben stejnými faktory, kterým je obecně připisováno oslabování státu, jako je šíření nároků na ,práva“ obklopující etnickou př́íslušnost, sexualitu a gender nebo ekologii: „Potřebujeme zákony upravující všechny tyto záležitosti a složité nároky na sociální zajištění, které implikuji““ (1997: 492). Poznamenejme však, že „národní“ komponent tohoto druhu expanzivního „národního státu“ je spíše metaforou pro jeho rozsah a infrastrukturu, velmi málo se podobající vylučující, homogenní a personifikované kolektivitě minulosti.

\section{Poděkování}

Toto je poslední ze série několika přednášek, jež jsem napsal jako hostující profesor na Russel Sage Foundation v New Yorku v letech 2002-2003. S lítostí musím prohlásit, že se zároveň jedná o poslední veřejnou možnost poděkovat Eriku Wannerovi a jeho velice vstřícným kolegům.

Přeložila Alice Navrátilová 


\section{Literatura}

Bade, K. J. 1984. Auswanderer, Wanderarbeiter, Gastarbeiter. Ostfildern: Scripta Mercaturae.

Bell, D. 1975. „Ethnicity and Social Change.“ In N. Glazer, D. P. Moynihan (eds.) Ethnicity, Cambridge, MA: Harvard University Press.

Blainey, G. 1984. All for Australia. North Ryde: Methuen Hayes.

Brubaker, R. 1992. Nationhood and Citizenship in France and Germany. Cambridge, MA: Harvard University Press.

Carens, J. 1987. „Aliens and Citizens: The Case for Open Borders.“ Review of Politics, 49 (2): 251-73.

CDU (Christlich-Demokratische Union Deutschlands) 2000. Arbeitsgrundlage für die Zuwanderungs-Kommission der CDU Deutschlands. Berlin, November. Online dokument dostupný z: <http://www.cdu.de>

Deutsch, K. W. 1957. Political Community and the North Atlantic Area. Princeton, NJ: Princeton University Press.

Dietrich, S. 2000. „Die Inländerfrage.“ Frankfurter Allgemeine Zeitung, 25 October, s. 1.

Dworkin, R. 1978. „Liberalism.“ In S. Hampshire (ed.) Public and Private Morality, Cambridge: Cambridge University Press.

Fetzer, J. S. 2000. Public Attitudes toward Immigration in the United States, France, and Germany. New York: Cambridge University Press.

Freeman, G. 1995. „Modes of Immigration Politics in Liberal Democratic States.“ International Migration Review, 29 (4): 881-902.

Goodwin-Gill, G. 1978. International Law and the Movement of Persons between States. Oxford: Clarendon Press.

Gosewinkel, D. 2001. Einbürgern und Ausschliessen. Göttingen: Vandenhoeck and Ruprecht. Guiraudon, V. 2000. Les Politiques d'immigration en Europe. Paris: L'Harmattan.

Hailbronner, K.; Renner, G. 2001. Staatsangehörigkeitsrecht. Munich: Beck.

Hampton, J. 1995. „Immigration, Identity, and Justice.“ In W. Schwartz (ed.) Justice in Immigration, New York: Cambridge University Press.

Hansen, R.; Weil, P. (eds.) 2002. Dual Citizenship, Social Rights, and Federal Citizenship in the US and Europe. Oxford: Berghahn.

Ignatieff, M. 2001. Human Rights as Politics and Idolatry. Princeton, NJ: Princeton University Press. Jacobson, D. 1996. Rights across Borders. Baltimore, MD: Johns Hopkins University Press. Joppke, Ch. 2001. ,,The Legal-Domestic Sources of Immigrant Rights.“ Comparative Political Studies, 34 (4): 339-66.

Joppke, Ch. 2004a. „The Retreat of Multiculturalism in the Liberal State.“ British Journal of Sociology, 55 (2): 237-57.

Joppke, Ch. 2004b. „Primordial Beliefs and Immigration Policy: The Case of Britain's Patrials.“ In J. Alexander, G. Marx, C. Williams (eds.) Self, Social Structure, and Beliefs: Exploration in Sociology, Berkeley: University of California Press.

Joppke, Ch. 2005a. Selecting by Origin: Ethnic Migration in the Liberal State. Cambridge, MA: Harvard University Press.

Joppke, Ch. 2005b. „Are Non-discriminatory Immigration Policies Reversible? Evidence from the United States and Australia." Comparative Political Studies, 38 (1). 
King, G.; Keohane, R. O.; Verba, S. 1994. Designing Social Inquiry. Princeton, NJ: Princeton University Press.

Kymlicka, W. 1995. Multicultural Citizenship. Oxford: Oxford University Press.

Kymlicka, W. 2002. „Territorial Boundaries.“ (Nepublikovaný rukopis.)

Lewis, M. D. 2000. The Company of Strangers: Immigration and Citizenship in Interwar Lyon and Marseille. Disertační práce, obor „History“, New York University.

Luhmann, N. 1982. The Differentiation of Society. New York: Columbia University Press.

Mann, M. 1997. „Has Globalization Ended the Rise and Rise of the Nation-State?“ Review of International Political Economy, 4 (3): 472-96.

Marx, A. 2002. „The Nation-State and its Exclusions.“ Political Science Quarterly, 117 (1): $103-26$.

Marx, A. 2003. Faith in Nation: Exclusionary Origins of Nationalism. New York: Oxford University Press.

Mill, J. S. 1991. Considerations on Representative Government. Buffalo, NY: Prometheus Books.

Miller, D. 1995. On Nationality. Oxford: Clarendon Press. Offe, C. 1998. „, ,Homogeneity“ and Constitutional Democracy.“ Journal of Political Philosophy, 6 (2): 113-41.

Orentlicher, D. 1998. „Citizenship and National Identity.“ In D. Wippmann (ed.) International Law and Ethnic Conflict, Ithaca, NY: Cornell University Press.

Pickus, N. 2001. „Which America? Nationalism among the Nationalists.“ (Nepublikovaný rukopis).

Rosberg, G. 1983. „Discrimination against the ,Nonresident“ Alien.“ University of Pittsburgh Law Review, 44: 399-407.

Rubio-Marin, R. 2000 Immigration as a Democratic Challenge. Cambridge: Cambridge University Press.

Schoenwaelder, K. 2004. „Why Germany’s Guestworkers Were Largely Europeans.“ Ethnic and Racial Studies, 27 (2): 248-65.

Scott, J. C. 1998. Seeing Like a State. New Haven, CT: Yale University Press.

Silagi, M. 1999. Vertreibung und Staatsangehörigkeit. Bonn: Kulturstiftung der deutschen Vertriebenen.

Slaughter, A.-M. 2004. „Disaggregated Sovereignty.“ Government and Opposition, 39 (2): 159-90.

Soysal, Y. 1994. Limits of Citizenship. Chicago: University of Chicago Press.

Stone-Sweet, A. 2000. Governing with Judges. Oxford: Oxford University Press.

Taguieff, P.-A. 2001. The Force of Prejudice. Minneapolis: University of Minnesota Press.

Tamir, Y. 1993. Liberal Nationalism. Princeton, NJ: Princeton University Press.

US Commission on Immigration Reform 1997. Becoming an American. Washington, DC: Government Printing Office.

Walzer, M. 1983. Spheres of Justice. New York: Basic Books.

Warner Parker, A. 1924. „The Quota Provisions of the Immigration Act of 1924.“ American Journal of International Law, 18 (4): 737-54.

Weber, M. 1971 [1895]. „Der Nationalstaat und die Volkswirtschaftspolitik.“ Obnovené vydání in M. Weber Gesammelte Politische Schriften. Tübingen: Mohr. 
Weil, P. 1995. „Racisme et discrimination dans la politique française de l'immigration.“ Vingtieme siecle, July-Sept.: 77-102.

Weil, P. 2001. „Access to Citizenship.“ In A. Aleinikoff , D. Klusmeyer (eds.) Citizenship Today. Washington, DC: Carnegie Endowment for International Peace.

White Paper (UK Government) 2002. Secure Borders, Safe Haven. London: The Stationery Office.

Wimmer, A. 2002. Nationalist Exclusion and Ethnic Conflict: Shadows of Modernity. Cambridge: Cambridge University Press.

Young, I. M. 1990. Justice and the Politics of Difference. Princeton, NJ: Princeton University Press.

Zolberg, A. 1999. „Matters of State: Theorizing Immigration Policy.“ In C. Hirschman, P. Kasinitz, J. DeWind (eds.) The Handbook of International Migration. New York: Russell Sage Foundation.

\section{Autor}

Christian Joppke je profesorem sociologie na Mezinárodní univerzitě v Brémách. Je autorem četných knih a publikací o sociálních hnutích, imigraci, občanství, státu, nejnověji Tř́dění podle původu: etnická migrace v liberálním státě (Harvard University Press, 2005). Kontakt: c.joppke@iu-bremen.de 